ISSN 1112-9867

Available online at $\quad$ http://www.jfas.info

\title{
ATTRIBUTES OF ETHICAL EMPLOYEES IN MALAYSIAN PUBLIC SECTOR: CONCEPTUAL CONTENT ANALYSIS AND PATTERN MATCHING ANALYSIS
}

\author{
Y. N. Marha ${ }^{1 *}$, M. Norazamina ${ }^{1}$, A. Suraya ${ }^{1}$, and A. Azizah ${ }^{2}$ \\ ${ }^{1}$ Faculty of Accountancy, Universiti Teknologi MARA, 23000 Dungun, Terengganu, \\ Malaysia \\ ${ }^{2}$ Faculty of Accountancy, Universiti Teknologi MARA, 40450 Shah Alam, Malaysia
}

Published online: 17 October 2017

\begin{abstract}
This study aims to explore the attributes of ethical employees in public sector and to pattern match the attributes with human behavior, social and ethics theories. A qualitative research is used by focusing on first-order attributes (through interviews) and second-order concepts (using theories to explain the facts). This study revealed nine (9) attributes toward ethical employees which were honest, follow instruction, presence of duties, respect, Islamic value, virtue values, loyalty, attachment and financial planning. Among the related theories to these attributes are the virtue ethics theory, attachment theory, social bonding theory, social learning theory and AlGhazali Theory of Virtue. This study suggested nine (9) genuine attributes of ethical employees that may enhance the public trust as well as the community trust towards state government ruler.
\end{abstract}

Keywords: ethical employees; Malaysian public sector; content analysis; pattern matching data analysis

Author Correspondence, e-mail: najihahm@tganu.uitm.edu.my

doi: http://dx.doi.org/10.4314/jfas.v9i5s.56

Journal of Fundamental and Applied Sciences is licensed under a Creative Commons Attribution-NonCommercial 4.0

International License. Libraries Resource Directory. We are listed under Research Associations category. 


\section{INTRODUCTION}

Malaysia's social economic and social life is improving from year to year throughout her 60 years of independency. In year 2015 and 2016, Malaysia celebrates her Independence Day with the theme of One Heart One Soul. Malaysian Public Sector is continually making an effort to serve the public with the best services. Malaysia through her 60 years also experienced financial scandals, corruptions, frauds such as in PERWAJA Steel Bhd, Bumiputra Malaysia Finance, Sime Darby, Transmile, LFE Corporation Bhd., Linear Corporation Bhd., Kenmark Industrial and PKFZ [1]. Currently, the issues of 1MDB Corporation and Tabung Haji have received attention from the public and media [2] [3]. Eventhough some members of Malaysian Public Sector had involved in these immoral activities for many years but they had never been arrested. Malaysia had received criticism regarding involvement of government agencies or business organizations in fraud and corruption [3] [4]. The agencies and organization have been criticised for not being efficient and failed to safeguard the public interests [4].

The Corruption Index reported that Malaysia remains a score of less than 50\% which indicates fraud, bribery and corruption is still occurring in Malaysia. Remain at low scores meaning government will incur huge financial losses and would bring bad image to Malaysian Public Sector. The score indicates that Malaysia needs to improve the organizations' internal self-precautionary. This can be done by assisting the government agencies/departments in upholding the organizational ethical self-identity. Malaysia has established Pillars of State Ideology and Federal Constitution that leads to many institutions and agencies such as Malaysian Institute of Integrity and Anti-Corruption Agency. Malaysian Institute of Integrity through its National Integrity Plan (NIP) aims to provide directions and guidance to the society and the nation at large. NIP aims to cultivate and strengthen a way of life for members of the society and the nation that upholds high moral ideals and ethical standards, thus becoming a nation of integrity. Thus, this aspiration can be achieved once each member in an organization upholds ethical values that become a part of organization ethical culture. Ensuring members of organization understand their responsibilities would ensure organizations and their members behave in integrity manner, no corruption and no violations of public right. 
Furthermore, this is to support Malaysia to be a developed country with high standard of ethical and integrity among her citizens before reaching year 2050. Public sector can play the role by having initial precaution efforts in preventing crime and corruption through inculcating sound ethical practices among its employees. Organization with ethical employees will assist in preventing further losses and in combating crimes.

The organizational ethical self-identity precautionary model that highlights ethical employees would assist the government agencies/departments to execute precaution monitoring and surveillance aspects of their management. This is to prevent mismanagement or misconduct and also in gaining the public trust. Hence, the objectives of this study are (i) to explore the attributes of ethical employees in public sector and (ii) to pattern match between ethical employees with human behavior and social theories.

\section{LITERATURE REVIEW}

In any organization, employees are the biggest assets that could support the survival of an organization. Ethical employees would be able to assist the organization in saving cost and time. Therefore, this would prolong the organizational survival. Ethical employees are known as those who do their work right and on time. They are also able to make good decision in ensuring the successfulness of an organization. Due to that, many procedures have been designed and implemented to employ ethical employees despite only selecting those with good academic result, knowledge, skill and abilities. Most organizations have made a thorough ethics screen through the interview session which includes an examination of behavioral information from resumes, reference checks and background checks, conducting personality surveys and posing ethical dilemmas. The discussion about work place during the interview session is to identify candidates with positive attitudes and characteristics that aligned with organizations' aims or goals. All of these are carried out to achieve the ethical culture that is sub element of business ethics as decribed in the new definition of corporate governance.

Ethical employee is defined as an employee voluntary behavior that does not violate significantly from organizational norms and in doing so protect the interest of an organization, its member, or both [5]. They behave in accordance to the sound moral principles inclusive of 
fairness, justice and trust that govern the behavior at the individual and organization levels [6]. [7] believed an ethical employee is a substantive basis to become an ethical leader. Even in mass media also highlighted the concern of having ethical employees. Bradwell Mhonderwa Business Ethics defined ethical employees as persons who are dedicated to do their jobs and are motivated to do the best [8].

[9] revealed two (2) siginifant factors that influence ethical employess namely ethical intention and organizational ethics. The findings support the concept of ethical congruence between individual (employees) and organization ethics. According to [10], employees' evaluations on justice and emotional responses are more positive when unethical employees were punished. The organization should not only provide the ethical rules without enforcement. The organization is expected to hold a proper ethical culture which can provide the employees a good ethical behavioural model. Nevertheless, a proper ethical culture could be achieved when the employees are inspired to act ethically [9]. Similarly, [11] revealed that employees' ethical behavior has significant relationship with ethical leadership and organization ethical climate. Moreover, the employees with high ethical values enable to inculcate a positive state of mind towards society and environment [12].

[13] discovered that different ideology leads to different employees' reaction towards the ethical codes. An employee with relativism ideology believes that the code of ethics does not uphold their moral behavior, while idealist adheres to the stipulated codes. Similarly, [14] found that ethical idealogy acts as an explanatory variable for ethical choice, in which employees with greater relativistic idealogy has greater likelihood to choose option unethical choice as compared to idealism ideology.

Lack of ethical employees may give negative impact to the workforce and to the organization and would put the organization at risk. Employees who cannot act ethically will create and cause potential ethical problems such as fraud and corruption. Hence, the literatures provide evidences that ethical employees will restore high trust toward the public sector which ensures the survival and continuity of the public sector.

\section{METHODOLOGY}

This study employed a qualitative research focusing on first-order concepts (through 
interviews) and second-order concepts (using theories to explain the facts). The findings of first-order concepts were through conducting interview with key informers (KI) of four government agencies/departments: statutory body (10), local authority (6), federation department (9) and state department (6) by using criterion purposive sampling. These organizations are well-known with identity of ethical practices while the key informers are those who have experienced and knowledgeable in the subject matters. The key personals from each government agencies/departments were interviewed by the researchers. The researchers' involvement during the interview is to ensure the validity and reliability of the study. The interview is based on protocol question and was recorded manually using the field notes. The recording was organized chronologically using both tacit (unspoken/implicit/unstated) and explicit (clear/open/unambiguous) information.

The data were analyzed by performing conceptual/theme content analysis using NVivo11 software. This was to determine the themes of ethical employees. The themes were then further analyzed using pattern matching data analysis. This was to match the attributes found through interviews with the human behavior and social theories (under second-order concepts). The value of using a pattern-matching technique is to link the qualitative research data to the theoretical proposition from related theory/ies [15], which explanations can be made on whether and why the patterns are matched or not [16]. By doing so, it will eventually result in greater validity and support to the theory or conceptual framework underpinning the study [16]. Both analyses will give confirmation that an ethical employee is a valid concept developed under organizational ethical self-identity precautionary model.

\section{RESULTS AND DISCUSSION}

\subsection{Qualitative Findings}

The gender of KI interviewed in this study is shown in Table 1. KIs are the managers/heads of departments/units in the respective statutory body (SB), local authority (LA), federation department (FD) and state department (SD). 
Table 1. Demographic (gender) of the respondents

\begin{tabular}{lcccc}
\hline & SB & LA & FD & SD \\
\hline No of respondents & 10 & 6 & 9 & 6 \\
Gender & $3 \mathrm{M}, 7 \mathrm{~F}$ & $5 \mathrm{M}, 1 \mathrm{~F}$ & $4 \mathrm{M}, 5 \mathrm{~F}$ & $0 \mathrm{M}, 6 \mathrm{~F}$ \\
\hline
\end{tabular}

Note: $\mathrm{M}=$ Male, $\mathrm{F}=$ Female

Conceptual/theme content analysis found nine (9) attributes of ethical employees which were honest, follow instruction, presence of duties, respect, Islamic value, virtue values, loyalty, attachment and financial planning. These findings were obtained from the conceptual/theme content analysis using Nvivo 11 as depicted in Fig.1.

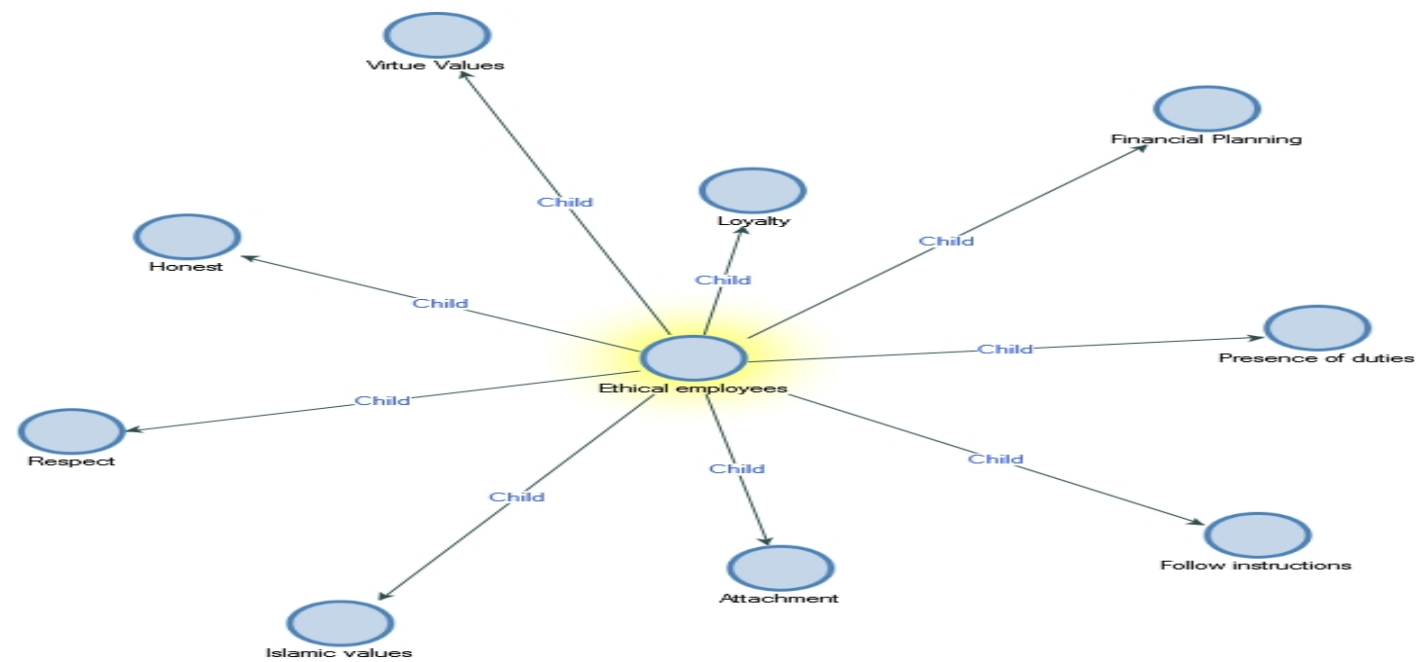

Fig.1. Attributes of ethical employee

[8] revealed six (6) attributes of ethical employees which consist of integrity, valuing diversity, co-operative, accountability, teamwork and commitment. This study found similar attributes when the KIs indicate ethical employee is concerning of honest, follow instruction, presence of duties, respect and loyalty. Nevertheless, this study discovered four (4) additional attributes which were not discussed in literature which are Islamic value, virtue values, attachment and financial planning. Table 2 shows the coverage of ethical employee attributes. 
Table 2. Ethical employees' attributes and sub-attributes

\begin{tabular}{|c|l|l|}
\hline & Attributes & Explanation/Sub attributes \\
\hline 1. & Honest & $\begin{array}{l}\text { Responsible } \\
\text { Integrity }\end{array}$ \\
\hline 2. & Follow instructions & $\begin{array}{l}\text { Confidentiality } \\
\text { Timeliness } \\
\text { Dress code }\end{array}$ \\
\hline 3. & Presence of duties & Discipline \\
\hline 4. & Respect & $\begin{array}{l}\text { Consideration } \\
\text { Teamwork } \\
\text { Communication }\end{array}$ \\
\hline 5. & Islamic value & Duty is ibadah \\
\hline 6. & Virtue values & $\begin{array}{l}\text { Neutral } \\
\text { Independent }\end{array}$ \\
\hline 9. & Financial Planning & Good in income management \\
\hline
\end{tabular}

\subsubsection{Honest}

In this study, the findings revelead that honest is the most important attribute of ethical employees. Honest attribute has been stressed by 12 KIs. KASTOff7, KWSPOff5, SUKOff1, SUKOff4 directly relate ethical employee as a person who is honest. According to KASTOff1 honest measures degree of responsibility of one person to his or her works and it indicates that a person has a good attitude (SUKOff4). Moreover, the employees should carry his/her real personality and this has been emphasized by KASTOff5 which declared that "An A rated staffs at the office is also an A rated person outside the office". This implies that, they are doing the right things at all times. Among the unethical acts prevailed in an organization are abuse of power (KASTOff3), misused of property, bribery (MBSBOff3), failed to perform the required tasks (MBSAOff1). In order to curb this issue, employees should make declaration on any 
investment made (KWSPOff3). Moreover, KWSPOff3 stressed that "in selecting vendor during purchasing process, employees must declare no relationship with the vendor".

\subsubsection{Follow Instructions}

The results of this study discovered that 11 KIs agreed that follow instructions should be seen as a must to the employees in any organisation. According to KASTOff1, ethical employee is defined as a person who follows instructions. KASTOff7 further added that an employee is considered ethical when she/he is accountable to her/his duties and responsibilities. Most KIs described follow instructions in three (3) perspectives; namely confidentiality, timeliness and dress code. In the context of employees, confidentiality is about the ability of a person not to disclose sensitive information and issue of the organisation to the third party (KWSPOff3). The second sub-attributes is timeliness, in which ethical employee should be always punctual (SUKOff4) and arrive at the office on time (MBSAOff5). Some KIs also believed that an appearance is an important indicator of ethical employee. Dress code represents an image to the organisation as well as individual image that someone should hold (KASTOff5).

\subsubsection{Presence of Duties}

Another important attributes of ethical employee is presence of duties in which 7 KIs concured to this attribute. The absenteeism is a chronic problem to most organization, and some KIs stressed the importance of discipline to an employee (MBSAOff1, SUKOff2, SUKOff6). According to KASTOff3, KWSPOff5, MBSBOff3 some of the employees are subjected to flexible working hours and such suppleness has been mistreated when they simply being absent from work. Moreover, SUKOff2 revealed a negative relationship between presence of duties and disciplinary action. The KI stated that, "a reduction in the disciplinary cases due is to the decline number of duty absenteeism". The findings suggest that organizations should find strategies to curb the absenteeism issue that may tarnish the organizational image and distort the operations of the organization.

\subsubsection{Respect}

Respect measures degree of appreciation towards something considered important. According to KASTOff7 ethical employee with the respect attribute is "a staff with a certain degree of consideration and know his/her duties and responsibilities". KASTOff5 and KASTOff5 believed that ethical employees must always maintain a good relationship with collegues, 
superiors and their subordinates in order to create high spirits environment. The endurance of this relationship is due to good communication and teamwork between each other in which they could always sit down and discuss any issues arised (KASTOff5).

In addition, respect could also be measured by the willingness of an employee to lend a hand to help senior officers that may later strengthen the relationship (KASTOff3) and better friendship (SUKOff4).

\subsubsection{Islamic Value}

The findings of this study discovered that Islamic value is one of the attributes of etchical employees (KWSPOff1, KWSPOff8, MBSAOff3). KWSPoff1 emphasized that instilling Islamic value in should be one of the organization's center of attentions. According to MBSAOff3 "duty is ibadah, is a way of seeking rezeki, we are giving service to the community so need to have strong integrity". Hence, the spirituality should be basis in guarding one self behavior (KWSPOff8).

\subsubsection{Virtue Values}

Virtue value is also known as a true value of one person and not related to external factors such as other individuals or environment. Two (2) KIs believed that ethical employees should uphold virtue value (KWSPOff3 and KWSPOff5). Ethical employees with virtue value could be seen from the attitude that such employees embrace (KWSPOff5). KWSPOff3 declared two (2) sub attributes of virtue values which consist of neutral and independent view without fear or favour.

\subsubsection{Loyalty}

Another attribute of ethical employees is loyalty (KWSPOff1). KWSPOff1 clearly mentioned that loyalty and pride should be embedded in the heart and soul of an employee. According to KWSP Off3, a loyal employee attaches with an organization for a longer period due to a special quality of such organization.

\subsubsection{Attachment}

Attachment can be described as interpersonal relationship between humans. In this study, only $1 \mathrm{KI}$ believed that attachment is an important attribute of ethical employees. KWSPOff5 agreed that ethical employee should have sense of self belonging towards organization.

\subsubsection{Financial Planning}

The last attribute of ethical employees is financial planning that has been emphasized by 
KASTOff6. This KI believed that an employee is ethical when he/she is good in managing his/her financial. The employee is responsible to ensure that the liabilities are matched with the income with reasonable amounts of savings for upcoming endurance.

These nine (9) attributes of ethical employee are further matched with several theories as shown in Table 3.

Table 3. Pattern matching ethical employees with relevant theories

\begin{tabular}{lll}
\hline & Ethical Employees & \multicolumn{1}{c}{$\begin{array}{c}\text { Pattern Matching of } \\
\text { theories }\end{array}$} \\
\hline 1 & Honest & Virtue Ethics Theory \\
2. & Follow instruction & Social Learning Theory \\
3. & Presence of duties & Social Bonding Theory \\
4. & Respect & Social Learning Theory \\
5. & Islamic values & AlGhazali Theory of Virtue \\
6. & Virtue values & Virtue Ethics Theory \\
7. & Loyalty & Social Bonding Theory \\
4. & Attachment & Attachment Theory \\
9 & Financial planning & Modern Portfolio Theory \\
\hline
\end{tabular}

\section{CONCLUSION}

This study has identified attributes of ethical employee in the Malaysian Public Sector which are useful aspects of ethical self-identity. Employees with these nine (9) ethical attributes act as a buffer for unethical conducts in an organization. The results of this study may assist the government agencies or departments to gain trust and confidence from the public. Moreover, this study will give clear ethical direction to employee that indirectly may lead to consistent and long survival of Malaysian Public Sector.

\section{ACKNOWLEDGEMENTS}

The authors gratefully acknowledge the research grant (Fundamental Research Grant Scheme) 
financed by Ministry of Higher Education.

\section{REFERENCES}

[1] William R. Linear blames weak internal control, Financial Daily, 2010

[2] The Star on Line. Tabung Haji: Three firms want to buy 1MDB land, 2015

[3] The Straits Times. Broad mandate' to probe Malaysia's 1MDB accounts: Auditor-General, 2015

[4] Siddiquee N A. Public accountability in Malaysia: Challenges and critical concerns. International Journal of Public Administration, 2005, 28(1-2):107-129

[5] Robinson S L, Bennett R J. A typology of deviant workplace behavior': A multidimensional scaling study. Academy of Management Journal, 1995, 3(2):555-572

[6] Wiley C. The ABC's of business ethics: Definitions, philosophies, and implementation. Industrial Management, 1995, 37(1):22

[7] Trevino L K, Hartman L P, and Brown M. Morale person and morale manager: How executives develop a reputation for ethical leadership. California Management Review, 2000, 42(4):128-142

[8] The Herald. Attributes of an ethical employees, 2017

[9] Elango B, Pau K, Kundu S K, and Paudel S K. Organizational ethics, individual ethics and ethical intentions in international decision-making. Journal of Business Ethics, 2010, 97, $543-561$.

[10] Trevino L K. Developing and changing organizational ethics: A cultural approach. Research in Organizational Change and Development, 1990, 4, 195-230

[11] Lu C, Lin C. The effects of ethical leadership and ethical climate on employee ethical behavior in the international port context. Journal of Business Ethics, 2014, 124, 129-223

[12] Potocan V, Mulej M, and Nedelko Z. The influence of employees' ethical behavior on enterprises' social responsibility. Systemic Practice and Action Research, 2013, 26, 497-511

[13] Putranta M P. Code implementation and code embeddedness: Perceptions of employees by ethical ideologies. Procedia- Social and Behavioral Science, 2016, 219, 598-605.

[14] Callanan G A, Rotenberry P F, Perri D F, and Oehlers P. Contextual factors as moderators of the effects of employee ethical idealogy on ethical decision making. 
International Journal of Management, 2009, 27(1):52-75

[15] Saunders M, Lewis P, and Thornhill A. Research methods for business students $\left(5^{\text {th }} \mathrm{Ed}\right)$, Essex Prentice Hall, 2009

[16] Yin R K. Case study research: Design and methods ( $3^{\text {rd }}$ Ed). Thousands Oaks, CA: SAGE Publication, 2003

\section{How to cite this article:}

Marha Y N, Norazamina M, Suraya A, Azizah A. Attributes of ethical employees in malaysian public sector: Conceptual content analysis and pattern matching analysis. J. Fundam. Appl. Sci., 2017, 9(5S), 788-799. 